\title{
ARTRITIS PSORIATIKA
}

\section{Faris Rizki Ardhan, Muhammad Akbar Hanardi, Dhila Thasliyah, Visakha Vidyadevi Wiguna, Ni Putu Yunandari}

Fakultas Kedokteran, Universitas Mataram, Indonesia

Email: farisardhn@gmail.com,muhammadakbarhanardi@gmail.com, , d.thasliyah@gmail.com, visakhawiguna@gmail.com, putuyunandari@gmail.com

\begin{abstract}
Abstrak
Tujuan penelitian ini adalah untuk mengetahui faktor risiko, pengobatan farmakologi dan pencegahan dari Artritis Psoriatika. Artritis Psoriatika adalah penyakit musculoskeletal kronik berkaitan dengan psoriasis. Setidaknya 5\% pasien psoriasis berkembang menjadi artritis psoriatika. Secara global insiden PsA mencapai 133 setiap 100.000 subjek pasien. Insidensi PsA per tahun sekitar 2,7 kasus per 100 orang dari pasien yang terdiagnosis psoriasis. Di Asia kasus PsA meningkat dari tahun 2000 hingga 2013 dengan prevalensi (per 100.000 penduduk) 11,12 menjadi 37,75. Berdasarkan sebuah penelitian di RSUP Sanglah Bali ditemukan sebanyak 6,3\% pasien PsA dari pasien psoriasis. Pasien PsA dapat ditemukan gambaran klinis seperti artritis perifer, enthesitis, daktilis, keterlibatan kulit, kuku, dan aksial. Faktor risiko artritis psoriatika antara lain obesitas, trauma fisik, merokok, lokasi psoriasis di tubuh, tingkat pendidikan dan faktor genetik. Pengobatan farmakologi PsA berdasarkan pedoman terbaru dari EULAR 2019 dan rekomendasi ACR. Kedua pedoman ini membahas pengobatan farmakologi berdasarkan gambaran klinis pada pasien. Tujuan dari terapi farmakologi untuk meningkatkan kualitas hidup pasien dengan memperbaiki keluhan simtomatik dan mencegah kerusakan struktural. Sebagai pencegahan dari PsA ialah menjaga berat badan agar tetap ideal, mengurangi konsumsi rokok, dan melakukan skrining sebagai deteksi dini. Artikel ini dibuat dengan metode systematic Review dari berbagai jenis sumber yang berasal dari jurnal ilmiah. PsA adalah kondisi kulit yang mengalami inflamasi kronis multisistemik yang terjadi di seluruh dunia, terjadi pada pria dan wanita dari segala usia, tanpa memandang asal etnis.
\end{abstract}

Kata kunci: Artritis Psoriatika; Faktor risiko PsA, Pedoman EULAR, Pedoman ACR

\section{Abstract}

To know the risk factors, pharmacological treatment and prevention of psoriatic arthritis. Psoriatic arthritis is a chronic musculoskeletal disease associated with psoriasis. at least 5\% of psoriasis patients develop psoriatic arthritis. Globally, the incidence of PsA reaches 133 per 100,000 patient subjects. The annual

\footnotetext{
Copyright holder: Faris Rizki Ardhan, Muhammad Akbar Hanardi, Dhila Thasliyah, Visakha Vidyadevi Wiguna, Ni Putu Yunandari (2021) 
incidence of PsA is about 2.7 cases per 100 people diagnosed with psoriasis. In Asia, PsA cases increased from 2000 to 2013 with a prevalence (per 100,000 population) of 11.12 to 37.75. Based on a study at Sanglah Hospital Bali found PsA patients as much as $6.3 \%$ of psoriasis patients. PsA patients may have clinical features such as peripheral arthritis, enthesitis, dactylitis, skin, nail, and axial involvement. Risk factors for psoriatic arthritis include obesity, physical trauma, smoking, location of psoriasis in the body, education level and genetic factors. Pharmacological treatment of PsA based on the latest guidelines from EULAR 2019 and ACR recommendations. These two guidelines discuss pharmacological treatment based on the patient's clinical picture. The goal of pharmacological therapy is to improve the patient's quality of life by improving symptomatic complaints and preventing structural damage. As a prevention, PsA maintains an ideal body weight, reduces cigarette consumption, and performs detection as an early detection.

Keywords: Arthritis Psoriatics; PsA risk factors; EULAR Guidelines; ACR Guidelines

Diterima: 07-11-2021

Direvisi: 10-12-2021

Diterbitkan: 20-12-2021

\section{Pendahuluan}

Psoriasis adalah kondisi kulit yang mengalami inflamasi kronis multisistemik. Paling sering muncul dengan plak eritematosa bersisik yang terjadi di daerah ekstensor siku dan lutut, terkadang pada daerah intergluteal, umbilikus, serta bagian lainnya dari tubuh (Ocampo et al., 2019). Artritis Psoriatika (PsA) adalah penyakit muskuloskeletal kronis yang berkaitan dengan psoriasis, setidaknya 5\% dari pasien psoriasis berkembang menjadi PsA. Penyakit ini paling sering muncul dengan artritis perifer, daktilitis, enthesitis, dan spondilitis (Singh et al., 2018).

Psoriasis terjadi di seluruh dunia, terjadi pada pria dan wanita dari segala usia, tanpa memandang asal etnis. Selain kulit, psoriasis dapat dikaitkan dengan radang sendi inflamasi yang dikenal sebagai PsA, yang melibatkan persendian tulang belakang dan persendian lainnya. Hal ini terjadi tanpa kehadiran antibodi spesifik dalam darah (spondyloarthropathy seronegatif) dan faktor rheumatoid (antibodi yang terbentuk di rheumatoid arthritis).

Sebuah tinjauan pustaka menunjukkan bahwa PsA mempengaruhi antara 1,3\% dan $34,7 \%$ dari pasien yang didiagnosis dengan psoriasis. Tidak ada data tentang kecenderungan jenis kelamin. Dalam penelitian pada populasi Amerika Serikat, diamati bahwa PsA lebih sering terjadi pada pasien Kaukasia dibandingkan kelompok etnis lain (World Health Organizations, 2018). PsA terjadi pada 20-30\% pasien dengan psoriasis yang datang ke klinik dermatologi. Sebuah meta-analisis memperkirakan prevalensi dan insiden PsA secara global, masing-masing, 133 setiap 100.000 subjek (95\%CI, 107-164 setiap 100.000 subjek) dan 83 setiap 100.000 orang-tahun (95\% CI, 41-167 setiap 100.000 orang-tahun) (Scotti, Franchi, Marchesoni, \& Corrao, 2018).

Suatu penelitian yang dilakukan oleh Eder, dkk. menemukan rate insidensi tahunan PsA adalah 2,7 kasus per 100 pasien psoriasis jika hanya memasukkan data kasus terkonfirmasi PsA. Insidensi meningkat menjadi 3,2 kasus per 100 pasien 
Faris Rizki Ardhan, Muhammad Akbar Hanardi, Dhila Thasliyah, Visakha Vidyadevi Wiguna, Ni Putu Yunandari

psoriasis jika memasukkan data kasus terkonfirmasi dan suspek PsA (Eder et al., 2016). Di Asia tepatnya Taiwan, prevalensi psoriasis pada individu berusia $\geq 16$ tahun, terutama PsA, meningkat dari 2000 hingga 2013. Prevalensi (per 100.000 penduduk) penyakit psoriatis antara tahun 2000 dan 2013 meningkat dari 11,12 menjadi 37,75 untuk PsA, dan dari 179,2 menjadi 281,5 untuk psoriasis. Insiden (per 100.000 orangtahun) meningkat dari 3,64 menjadi 6,91 di PsA, sementara tidak ada perubahan signifikan pada psoriasis Studi ini menemukan bahwa rate insiden PsA secara signifikan lebih tinggi dibandingkan psoriasis (Wei, et al., 2018).

Di Indonesia, berdasarkan penelitian yang dilakukan oleh Segar, Praharsini dan Indira pada tahun 2017-2018 di RSUP Sanglah, Bali didapatkan proporis pasien yang mengalami PsA yakni sebanyak 6,3\% dari pasien psoriasis (Segar et al, 2019).

\section{Metode penelitian}

Metode yang digunakan dalam penulisan ini menggunakan systematic review dari berbagai jenis sumber yang berasal dari jurnal ilmiah. Pencarian sumber artikel dilakukan melalui portal online publikasi jurnal seperti National Center for Biotechnology Information / NCBI (ncbi.nlm.nih.gov) dan Google Scholar (scholar.google.com). Kata kunci yang digunakan "Psoriatic arthritis", "Risk Factors of PsA", "Treatment of Psoriatic Arthritis", and "Clinical Presentation of Psoriatic Arthritis".

\section{Hasil dan Pembahasan}

\section{Gambaran Klinis}

Sekiar $15-20 \%$ kasus, artritis muncul sebelum terjadinya psoriasis, namun dapat juga muncul secara bersamaan. Adapun Gmabaran klinis yang sering ditemukan pada pasien PsA meliputi, Kekakuan dan nyeri. Enthesitis yaitu peradangan pada tendon atau ligamen pada tulang, lebih sering terjadi pada perlekatan tendon achilles dan plantar fascia ke kalkaneus. Daktilitis, yaitu peradangan pada jari tangan atau kaki menyebabkan pembengkakan. Lesi kulit seperti plak bersisik dan eritematosa, lesi gutata, dan eritroderma. Psoriasis dapat terjadi di kulit kepala, perineum, celah intergluteal, dan umbilikus serta perubahan pada kuku yang berlubang (Overcash et al, 2021).

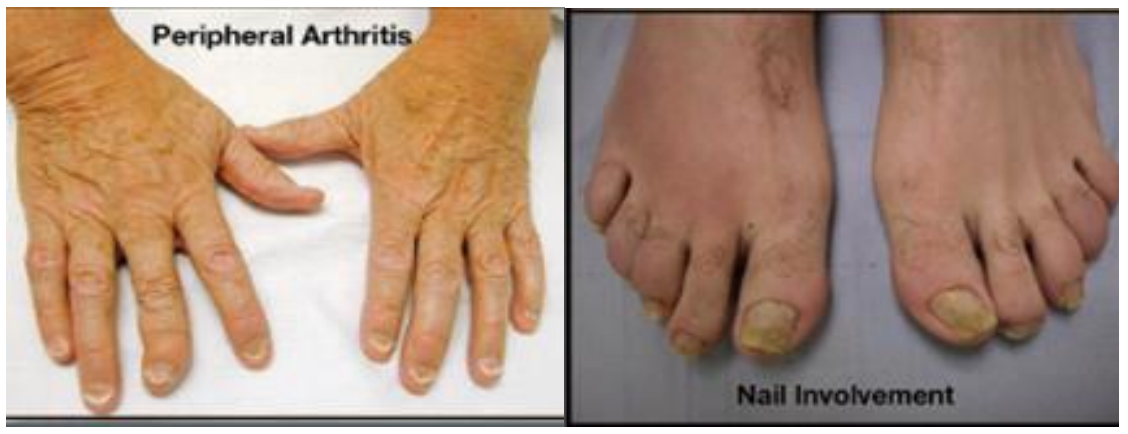



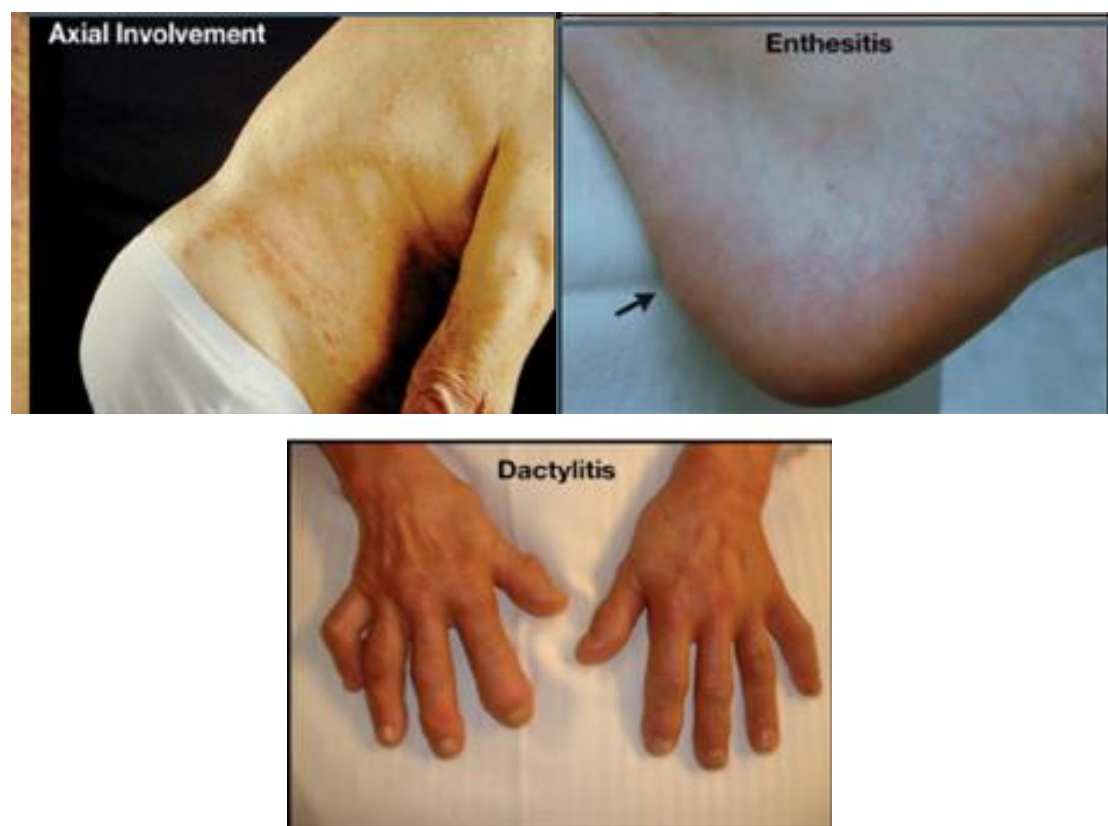

\section{Gambar 1. Gambaran Klinis Artritis Psoriatika dikutip dari Overcash et al, 2021. Patogenesis}

Patogenesis terjadinya PsA berkaitan dengan sel T. Sel CD 4+ dan CD 8+ yang ditemukan pada kulit dan sendi pasien PsA melakukan ekspansi ke daerah sinovium. Sel CD 4+ lebih banyak ditemukan pada kulit dan CD 8+ lebih banyak pada cairan synovial. Kedua sitokin ini menstimulasi sitokin proinflamasi. Selanjutnya interaksi antara sel T, sel dendritik, sinoviosit, dan keratinosit akan menimbulkan lingkaran yang akan berkembang menjadi peradangan dan mendorong kerusakan tulang pada persendian dan lesi pada kulit. Selain itu, sel-sel sistem kekebalan seperti makrofag penghasil TNF- $\alpha$ ), neutrofil, dan sel mast banyak ditemukan pada sinovium. Sel dendritik juga mengekspresikan IL-23 dan merangsang polarisasi sel T naif menjadi sel $\mathrm{T}$ penghasil interleukin (IL) -17 . Sel CD 8+ T dalam cairan sinovial pasien PsA juga memproduksi IL-17. TNF- $\alpha$ dan IL-17 bersinergi untuk merangsang terjdinya angiogenesis, meningkatkan infiltrasi nuklir polimorfo di lokasi penyakit (dengan menginduksi produksi IL-6 dan IL-8 oleh fibroblas dikulit dan sendi) dan mempromosikan resorpsi tulang melalui aktivasi osteoklas. Sitokin-sitokin bersama dengan produk proinflamasi tersebut menyebabkan terjadinya sensasi nyeri pada sendi dan kulit serta kekakuan pada sendi pasien dengan PsA (Overcash et al, 2021).

Peran IL-23 juga diyakini dapat menyebabkan peradangan pada PsA. Adanya polimorfisme nukleotida dalam reseptor IL-23 dan kadar serum subunit IL-12/23 p40 lebih tinggi pada pasien PsA. IL-23 merupakan sitokin yang berpotensi terjadinya patogenesis PsA. IL-23 dapat memicu PsA dengan aktivasi CD3 + CD4-CD8entheseal, yang nantinya dapat meningkatkan ekspresi TNF dan IL-6 pada entesitis. Ekspresi IL-23 yang berlebihan dapat memicu peradangan pada enthesitis dengan cara menyebar ke sinovium yang berdekatan. IL-23 meningkatkan terjadinya inflamasi melalui IL-17 dan TNF, sedangkan peningkatan produksi IL-22 mengakibatkan pembentukan tulang baru (Amy S. Kehl, Maripat Corr, 2016). 
Faris Rizki Ardhan, Muhammad Akbar Hanardi, Dhila Thasliyah, Visakha Vidyadevi Wiguna, Ni Putu Yunandari

Gen terpenting yang terlibat dalam pathogenesis psoriasis adalah gen PSORS1 pada kromosom 6p, yang mengandung alel HLA-Cw6. Alel HLACw6 sangat terkait dengan psoriasis plak dan psoriasis gutata. HLA B-13 dan HLA B17 juga sangat terkait dengan psoriasis gutata dan eritroderma. Mekanisme peradangan kulit pada psoriasis cukup kompleks dan melibatkan berbagai sitokin, kemokin, dan faktor pertumbuhan yang mengakibatkan gangguan regulasi keratinosit, sel radang, dan pembuluh darah sehingga lesi tampak menebal dengan skuama tebal berlapis. Sel $\mathrm{T}$ diketahui berperan penting dalam patogenesis lesi kulit psoriasis. Aktivasi sel $\mathrm{T}$ dalam pembuluh limfe terjadi setelah antigen presenting cell (APC) mempresentasikan antigen melalui Major Histocompatibility Complex (MHC) dan diikat oleh sel T naif.

Pengikatan sel $\mathrm{T}$ terhadap antigen selain melalui reseptor sel $\mathrm{T}$, dilakukan juga oleh ligan dan reseptor tambahan yang dikenal sebagai kostimulasi. Setelah teraktivasi, sel $\mathrm{T}$ berproliferasi menjadi sel $\mathrm{T}$ efektor dan sel $\mathrm{T}$ memori yang kemudian masuk ke dalam sirkulasi sistemik dan bermigrasi ke kulit. Sel CD4+ merupakan subset sel T di dermis yang terpolarisasi oleh $\mathrm{T}$ helper 1 (Th1), sementara CD8+ pada epidermis terpolarisasi oleh $\mathrm{T}$ sitotoksik (Tc1) sehingga pada lesi psoriasis ditemukan banyak sitokin. Subset lain dari CD4+ adalah IL-17 (Th17) dan IL-22 (Th22) yang berperan mempertahankan inflamasi kronik pada psoriasis. Jalur imunopatogenik psoriasis pada tahap selular dan molekular penting untuk menentukan pemilihan terapi psoriasis, khususnya penggunaan bahan biologik yang bekerja secara spesifik pada limfosit $\mathrm{T}$ dan sitokin TNFa, IL-12, IL-23, dan IL-17A (Rendon et al., 2019).

\section{Faktor Risiko}

\section{Obesitas}

Obesitas didefinisikan sebagai indeks massa tubuh (IMT) di atas 30. IMT diukur dengan membagi berat badan dalam kilogram dengan kuadrat tinggi badan dalam meter (World Health Organizations, 2020). Peningkatan IMT menjadi salah satu faktor risiko terjadinya PsA. Obesitas terbukti meningkatkan risiko sebesar $75 \%$ yang signifikan secara statistik. IMT dilaporkan sebagai faktor risiko PsA yang bergantung dosis (dosedependent) di antara pasien psoriasis dan populasi umum. Mekanisme yang mendasari hubungan kausal antara PsA dan obesitas tidak sepenuhnya dipahami. Namun, penjelasan yang saat ini diterima adalah bahwa kondisi inflamasi sistemik dan kronis derajat rendah pada subjek obesitas menunjukkan peningkatan sitokin inflamasi (tumor necrosis $\alpha$ (TNF- $\alpha$ ), interleukin (IL) -1, IL-6, IL-8, IL-17 dan IL-23, dll) dan perubahan adipokin (leptin dan adiponektin) (Xie, Huang, Deng, Gao, \& Zhang, 2020).

\section{Trauma Fisik}

Risiko PsA meningkat secara signifikan pada pasien psoriasis yang mengalami cedera traumatis, terutama trauma fisik (misalnya patah). Konsep mengenai kompleks sinovioentheseal menjadi penjelasan ilmiah untuk trauma biomekanik sebagai peristiwa awal di patogenesis PsA. Berbeda dengan lokasi kerangka lainnya, entheses menahan stres biomekanik yang lebih tinggi, yang dapat memicu kaskade sitokin inflamasi oleh monosit dan infiltrasi limfosit, menghasilkan respon inflamasi artikular, menyebabkan 
sinovitis, proliferasi dan degenerasi jaringan fibrosa sinovial. Individu dengan psoriasis yang mengalami trauma fisik yang diibaratkan sebagai second hit dapat menyebabkan transisi psoriasis ke PsA (Xie, Huang, Deng, Gao, \& Zhang, 2020).

\section{Merokok}

Prevalensi terjadinya psoriasis lebih tinggi pada orang yang merokok dibandingkan yang tidak merokok. Merokok dapat mengakibatkan perubahan biokimia seperti peningkatan radikal bebas yang dapat mengaktifkan aktivasi mitogen protein kinase, jalur JAK-STAT yang berperan dalam inflamasi sel, meningkatkan peroksidasi lipid dan mengubah respon imun. Rendahnya tingkat karbon monoksida pada perokok dapat menghambat pelepasan sitokin pro-inflamasi (TNF-a, IL-1b, IL-8) dan meningkatkan IL-10 sehingga dapat mengakibatkan terjadinya artritis psoriatika. Nikotin pada rokok dapat mengaktifkan pelepasan berbagai sitokin seperti IL-2, IL-12, TNF dan faktor perangsang koloni granulosit-makrofag, serta menstimulasi vascular endothelial growth factor (VEGF) yang dapat menyebabkan terjadinya risiko psoriasis, nikotin juga dapat menghambat intraseluler jalur pro-inflamasi melalui pengaktifan reseptor asetilkolin nikotinik $\alpha 7$ (Gazel et al., 2020).

\section{Lokasi Psoriasis di Tubuh}

Lokasi awal lesi psoriasis menjadi salah satu faktor terjadi PsA. Psoriasis pada daerah kuku secara konsisten dikaitkan dengan risiko yang lebih tinggi untuk terjadi PsA. Hubungan anatomis yang erat antara kuku dan jaringan dari serat di etheses yang menghubungkan ke tendon ekstensor dan ligamen kolateral. Pada penelitian Eder et al menyatakan bahwa hanya kehadiran pitting kuku merupakan sebuah prediktor pengembangan PsA (Lihi Eder, 2016).

\section{Faktor genetik}

Psoriasis dan PsA berkaitan dengan alel MHC kelas I. Gen HLA-B27, HLAB38, HLA-B08, dan HLA-B39 telah diobservasi pada pasien dengan PsA. Selai itu, Gen reseptor mirip imunoglobin sel pembunuh atau Killer-cell immunoglobin-like receptor (KIR) diduga menjadi gen yang rentan dengan kejadian PsA. . Selain itu, sel T helper tipe 17 (Th17) subtype ILI2B dan IL23R diidentifikasi pada PsA, serta pada region yang lain pada kromososm 5q31 juga diidentifikasi menjadi penanda untuk PsA. (Ocampo D and Gladman, 2019).

\section{Manajemen Terapi}

\section{Psoriatika.}

\section{Rekomendasi EULAR 2019 Untuk Pengobatan Farmakologi Artritis}

Prinsip-prinsip dalam pengobatan farmakologi artritis psoriatika dari EULAR tahun 2019 tidak berubah jika dibandingkan tahun 2015. Prinsip A mengacu pada PsA yang heterogenis dan berpotensi parah. Prinsip B membahas pentingnya pengambilan keputusan bersama. Prinsip C menjelaskan pentingnya ahli reumatologi sebagai pemberi perawatan utama untuk pasien PsA. Prinsip D menerangkan tujuan pengobatan adalah mengatasi inflamasi dan memperbaiki kualitas hidup. Prinsip E menegaskan kembali pentingnya semua manifestasi muskuloskeletal dalam pertimbangan pengobatan. Prinsip 
Faris Rizki Ardhan, Muhammad Akbar Hanardi, Dhila Thasliyah, Visakha Vidyadevi Wiguna, Ni Putu Yunandari

F pada tahun 2015 menggunakan istilah manifestasi "ekstra-artikular" namun pada saat ini diubah menjadi istilah manifestasi "non-muskuloskeletal" yang mengacu pada keterlibatan organ pada PsA (Gossec et al., 2020).

Adapun prinsip-prinsip pengobatan farmakologi PsA berdasarkan EULAR 2019:

A. Artritis Psoriatika merupakan penyakit yang bersifat heterogen dan berpotensi menjadi parah, sehingga diperlukan pengobatan multidisiplin.

B. Pengobatan pada pasien Artritis Psoriatika harus dengan pengobatan terbaik dan berdasarkan keputusan antara pasien dan ahli reumatologi dengan mempertimbangkan keefektifan, keamanan, dan biaya.

C. Ahli reumatologi adalah spesialis yang merawat pasien Artritis Psoriatika terutama pada manifestasi yang melibatkan muskuloskeletal.

D. Ahli reumatologi dan dokter kulit juga harus bekerja sama dalam diagnosis dan manajemen Artritis Psoriatika yang melibatkan manifestasi pada kulit.

E. Tujuan utama pengobatan pada pasien Artritis Psoriatika adalah untuk meningkatkan kualitas hidup yang berhubungan dengan kesehatan, melalui pengendalian gejala, pencegahan kerusakan struktural, serta mengembalikan fungsi sosial. Mengatasi peradangan pada Artritis Psoriatika merupakan langkah utama untuk mencapai tujuan tersebut.

F. Dalam mengambil keputusan pengobatan diperlukan pertimbangan dari setiap manifestasi muskuloskeletal.

G. Dalam menangani pasien Artritis Psoriatika, harus dipertimbangkan juga manifestasi non muskuloskeletal seperti pada kulit, mata, saluran pencernaan, komorbiditas, penyakit kardiovaskular, dan depresi (Gossec et al., 2020). 


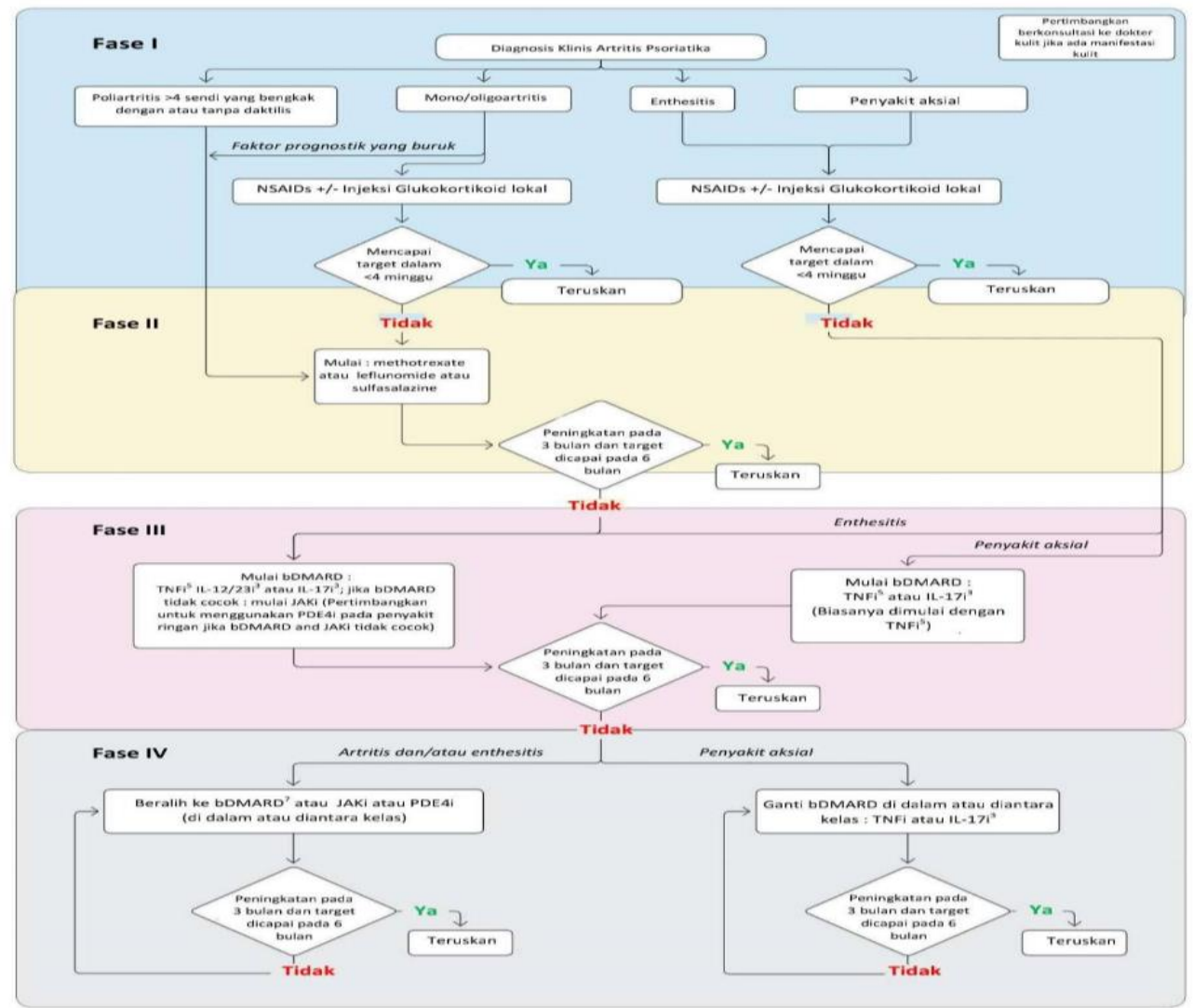

Gambar 4. Algoritma EULAR 2019 untuk pengobatan PsA dengan pengobatan nontopikal farmakologis dikutip dari Gossec et al., 2020.

Pengobatan ditujukan untuk mencapai target remisi dengan secara teratur menilai aktivitas penyakit dan menyesuaikan terapi yang tepat.

Rekomendasi ini mengedepankan strategi Treat to Target (T2T). Strategi ini menyatakan bahwa remisi atau aktivitas penyakit yang rendah seharusnya ditargetkan. Remisi dapat dilihat dengan adanya penghentian peradangan. Dalam pengobatan dengan strategi T2T, yaitu dilakukan dengan pemberian obat-obatan diberikan dari waktu ke waktu yang sebelumnya sudah ditentukan dengan tujuan akhir mencapi remisi (tidak adanya tanda atau gejala aktivitas penyakit). Pengobatan T2T bergantung pada aktivitas penyakit dan kesehatan secara keseluruhan, dengan pemantauan yang dilakukan setiap bulan. Setiap kunjungan dilakukan evaluasi apakah tujuan sudah tercapai. Jika tidak tercapai, maka dosis dapat ditingkatkan, pemberian kelas obat yang berbeda atau penambahan obat baru. Proses ini berlanjut hingga mendekati remisi atau aktivitas penyakit menurun serendah mungkin. Dengan demikian, tujuan akhir T2T dalam PsA adalah untuk menghilangkan peradangan sendi dan mencegah kerusakan sendi struktural, sehingga memaksimalkan kualitas hidup dan fungsi yang berhubungan dengan kesehatan, sambil meminimalkan kecacatan (Smolen et al., 2017).

1. Non-steroidal anti-inflammatory drugs (NSAID) dapat digunakan untuk mengatasi tanda dan gejala dari muskuloskeletal.

Versi rekomendasi sebelumnya, NSAID selalu direkomendasikan untuk meredakan gejala. Penggunaan NSAID harus selalu dipertimbangkan dengan hati-hati, 
Faris Rizki Ardhan, Muhammad Akbar Hanardi, Dhila Thasliyah, Visakha Vidyadevi Wiguna, Ni Putu Yunandari

terutama pada populasi dengan komorbid seperti penyakit kardiovaskular. Pada pasien artritis perifer, penggunaan NSAID harus dikombinasikan dengan Disease-modifying antirheumatic drugs (DMARDs). Apabila diberikan NSAID monoterapi tanpa DMARDs, tidak boleh diberikan melebihi 1 bulan jika tanda dan gejala masih ada, dan kemungkinan pengobatan lainnya harus dipertimbangkan. Pada pasien dengan psoriasis kulit, NSAID belum menunjukkan keefektifannya (Gossec et al., 2020).

2. Injeksi glukokortikoid merupakan terapi tambahan pada Artritis Psoriatika. Glukokortikoid sistemik dapat digunakan secara hati-hati dengan dosis rendah.

Rekomendasi ini tidak berubah dari guideline 2015, namun diurutkan ulang agar selaras dengan fase pengobatan yang diberikan. Perlu dicatat bahwa terapi glukokortikoid hanya dapat digunakan dalam waktu singkat. Satgas tidak merokemendasikan pemberian glukokortikoid pada penyakit aksial (Gossec et al., 2020).

3. Pasien dengan poliatritis, harus diberikan conventional synthetic diseasemodifying antirheumatic drugs (csDMARD) dengan cepat, penggunaan methotrexate (MTX) lebih dianjurkan jika ada manifestasi pada kulit.

Pasien dengan poliartritis harus menggunakan csDMARD sebagai lini pertama atau digunakan jika setelah mengonsumsi NSAID dalam waktu singkat. Dari pendapat para ahli bahwa penggunaan methotrexate pada Artritis Psoriatika masih tergolong langka. Namun, dari sebuah studi SEAM-PSA menerangkan bahwa methotrexate memiliki khasiat serupa dengan etanercept untuk Artritis Psoriatika, karena kesamaan keefektifannya, serta perbedaan harga maka studi ini lebih lanjut mendukung untuk menempatkan methotrexate dan $c s D M A R D$ pada bagian atas algoritma terapi.

Penggunaan methotrexate disorot diantara $c s D M A R D$ lainnya, terutama untuk pasien dengan manifestasi kulit yang luas, yakni keterlibatan area permukaan tubuh $>10 \%$ atau yang menyebabkan perubahan kualitas hidup seperti pada wajah, tangan, kaki, atau alat kelamin. Disisi lain, methotrexate mengarah pada hepatotoksisitas. Dosis optimal methotrexate direkomendasikan $25 \mathrm{mg} / \mathrm{minggu}$ dengan suplementasi folat. CSDMARD lainnya yang efektif untuk pengobatan psoriasis astritis meskipun lebih rendah dalam mengobati manifestasi kulit ialah leflunomide dan sulfasalazine. Terapi csDMARD tidak boleh dilanjutkan, jika target pengobatan tidak tercapai dalam 6 bulan (Gossec et al., 2020).

4. Pada pasien dengan monoartritis atau oligoartritis terutama dengan faktor prognostik yang buruk seperti kerusakan struktural, laju endap darah tinggi, dan daktilis, maka penggunaan $c s D M A R D$ harus dipertimbangkan.

Rekomendasi ini menekankan bahwa pasien dengan penyakit oligoartikular harus menerima $c S D M A R D$ dengan cepat jika ada faktor prognostik yang buruk. Namun terkait rekomendasi oligoartikular masih berdasarkan pendapat ahli bukan dari data. Salah satu faktor prognostiknya yakni daktilis yang sebelumnya ditangani bersama dengan enthesitis. Namun, sekarang telah dipisahkan karena satgas mempertimbangkan bahwa daktilis berbeda dalam hal patofisiologi, diagnosis, dan prognosis. Hal ini terkait 
dengan perubahan radiografik pada PsA, sedangkan pada enthesitis tidak terjadi perubahan yang dimaksud. Studi terbaru menunjukkan setidaknya ada beberapa keefektifan methotrexate untuk pengobatan daktilis. Perlu dicatat bahwa NSAID belum menunjukkan adanya kemanjuran dalam menangani daktilis (Gossec et al., 2020).

5. Pada pasien dengan artritis perifer jika diberikan csDMARD namun respon tidak adekuat, maka dapat digunakan terapi bioloigical agent diseasemodifying antirheumatic drugs (bDMARD), jika ada manifestasi pada kulit dapat digunakan inhibitor IL-17 atau IL12/23.

Rekomendasi ini ditujukan pada pasien dengan arthritis perifer yang mengalami kegagalan pengobatan atau intoleransi terhadap setidaknya satu $c s D M A R D$. Pada pasien ini, satgas merekomendasikan $B D M A R D$. Pada beberapa pasien, terutama mereka yang tidak memiliki faktor prognostik buruk, mungkin diindikasikan untuk menggunakan csDMARD kedua sebelum memakai $b D M A R D$. Namun jika ada keterlibatan penyakit aksial maka penggunaan awal bDMARDs boleh diusulkan karena $c s D M A R D s$ tidak efektif dikondisi ini (Gossec et al., 2020).

Pembaruan rekomendasi tidak lagi membedakan antara inhibitor TNF, inhibitor IL-12/23, dan inhibitor IL-17. Kemanjuran TNFi untuk PsA saat ini menunjukkan bahwa kejadian keganasan tidak meningkat. Studi terbaru menargetkan IL-23-p19 subunit (guselkumab, risankizumab, tildrakizumab) menunjukkan keefektifan yang sangat baik untuk psoriasis. Tingkat keamanan juga perlu diperhatikan dari bDMARD ini, risiko TNFi dalam jangka panjang termasuk aman, IL17i risikonya dapat meningkatkan kejadian kandidiasis lokal dan kemungkinan peningkatan risiko penyakit radang usus. Sebaliknya, IL-12/23i dan IL-17i telah menunjukkan efektivitas yang lebih besar pada kulit daripada TNFi dalam uji klinis psoriasis. Sehingga penggunaan IL12/23i dan IL-17i direkomendasikan apabila ada manifestasi pada kulit. Saat ini rekomendasinya adalah melanjutkan MTX dengan bDMARD. Tetapi dari satgas belum mendapatkan bukti bahwa terapi kombinasi lebih berkhasiat daripada monoterapi. Disarankan untuk mengurangi dosis MTX pada pasien yang menunjukkan respon baik untuk menghindari toksisitas dari MTX (Gossec et al., 2020).

6. Pada pasien dengan artritis perifer dan respon yang kurang baik terhadap setidaknya satu $c S D M A R D$ dan $B D M A R D$, atau saat penggunaan $b D M A R D$ tidak cocok, inhibitor JAK dapat dipertimbangkan untuk digunakan.

Saat ini, satu-satunya inhibitor JAK yang disetujui untuk penggunaan pada PsA adalah tofacitinib. Tofacitinib efektif untuk pengobatan yang melibatkan manifestasi pada sendi, namun pada keterlibatan manifestasi kulit keefektifannya lebih rendah. Menurut European Medicines Agency, tofacitinib harus diresepkan dengan MTX. Sampai saat ini, 2 inhibitor JAK sedang dalam tahap pengembangan untuk PsA. Satgas mengusulkan penggunaan inhibitor JAK setelah adanya intoleransi ke setidaknya satu bDMARD atau ketika dianggap bDMARD tidak cocok. Tidak cocok disini misalnya ketidakpatuhan dalam menggunakan injeksi atau pasien lebih condong menggunakan obat oral (Gossec et al., 2020). 
Faris Rizki Ardhan, Muhammad Akbar Hanardi, Dhila Thasliyah, Visakha Vidyadevi Wiguna, Ni Putu Yunandari

7. Pada pasien dengan enthesitis yang jelas dan respon yang tidak memadai terhadap NSAID atau injeksi glukokortikoid lokal, penggunaan bDMARD sebaiknya dapat dipertimbangkan.

Penyakit enthesitis merupakan masalah yang kompleks di PsA. Pemeriksaan sonografi atau MRI dapat menjadi pemeriksaan penunjang untuk mendiagnosis enthesitis. Pada pasien dengan enthesitis, NSAID dan glukokortikoid lokal merupakan pengobatan lini pertama. Enthesitis disini mengacu pada peradangan tulang, dan istilah "jelas" sekarang ditambahkan untuk menghindari peralihan fokus pada manifestasi nyeri yang berlebihan (Gossec et al., 2020).

8. Pada pasien dengan penyakit aksial yang aktif dan memiliki respon yang kurang baik terhadap NSAID, terapi dengan $B D M A R D$ harus dipertimbangkan, berdasarkan praktek saat ini yang digunakan adalah TNFi. Apabila ada keterlibatan kulit dapat digunakan inhibitor IL-17.

Dalam situasi dominan penyakit aksial, TNFi masih mewakili sebagai pengobatan dari lini pertama $b D M A R D$. Dalam PsA penyakit aksial dengan adanya keterlibatan kulit, maka inhibitor IL-17 lebih direkomendasikan daripada TNFi, mengingat lebih tingginya khasiat IL-17 pada kulit. Namun perlu diingat dalam kasus penyakit radang usus atau uveitis yang terjadi bersamaan, suatu TNFi lebih direkomendasikan. Sebagai catatan juga bahwa IL-12/23 tidak menjukkan keefektifan dalam penyakit aksial (Gossec et al., 2020).

9. Pasien yang mengalami kegagalan respon atau intoleransi terhadap $b D M A R D$, maka harus dipertimbangkan perubahan ke $b D M A R D$ lain dalam satu kelas atau targeted synthetic disease-modifying antirheumatic drugs (tsDMARD).

Sampai saat ini hasil uji coba yang tersedia menyarankan beralih obat dalam satu kelas sehingga satgas setuju keputusan ini, akan logis jika berubah kelas setelah terjadi kegagalan dua kali dalam kelas tertentu. Satgas membahas juga penggunaan abtacept yang telah disetujui untuk digunakan di PsA. Namun penggunaannya masih dibatasi karena mengingat kemanjurannya relatif rendah (Gossec et al., 2020).

10. Pada pasien dengan remisi berkelanjutan, pengurangan DMARD dapat dipertimbangkan.

Dikatakan sebagai remisi berkelanjutan jika aktivitas penyakit yang rendah terjadi setidaknya selama 6 bulan berturut-turut. Satgas memutuskan dan menawarkan pedoman tapering karena dianggap aspek penting dalam manajemen modern terutama bila remisi berkelanjutan telah tercapai. Rekomendasi tersebut tidak bermaksud untuk mendorong dokter agar menghentikan pengobatan melainkan untuk mencoba menemukan dosis efektif terkecil, baik melalui pengurangan dosis atau interval perpanjangan (Gossec et al., 2020).

Rekomendasi untuk terapi farmakologis dasar pada pengobatan Artritis Psoriatika berdasarkan American College of Rheumatology/National Psoriasis

1. Artritis Psoriatika yang sebelumnya mendapat pengobatan dari kelompok OSM 
Dapat menggunakan obat lainnya dari kelompok yang sama, yaitu OSM setelah itu baru dipertimbangkan menggunakan obat dari kelompok lainnya. Obat IL12/23i direkomedasikan daripada CTLA4-Ig dan JAK inhibitor. Pada pasien dengan PsA berat dapat digunakan obat IL-12/23i atau IL17i. Tofacitinib dapat digunakan sebagai pengganti TNFi pada penderita tanpa psoriasis berat yang memilih pengobatan oral. Pengobatan dengan kombinasi methotrexate digunakan sebagai pengganti monoterapi pada pasien dengan psoriasis parah, memiliki respon parsial terhadap methotrexate, dan menderita uveitis (Gladman et al., 2020).

2. Artritis Psoriatika yang sebelumnya diberi TNFi sebagai monoterapi atau terapi kombinasi

Direkomendasikan menggunakan obat lain dari kelompok yang sama. IL-12/23i, IL-17i, abatacept, dan tofacitinib digunakan apabila terdapat kegagalan terapi oleh TNFi atau efek samping yang cukup berat akibat TNFi. Jika terdapat psoriasis berat, bisa diganti dengan IL-12/23i. Abatacept dapat menjadi pengganti jika terjadi infeksi berulang atau serius tanpa adanya psoriasis. Tofacitinib dapat digunakan jika terapu oral lebih dipilih oleh penderita (Gladman et al., 2020).

3. Artritis Psoriatika yang sebelumnya diberi IL-17i sebagai monoterapi

Disarankan untuk beralih ke TNFi, IL012/23i, dikombinasikan dengan methotrexate, atau menggunakan IL17i yang berbeda. Pengobatan IL-12/23i bila penderita sudah mengalami psoriasis parah atau kontraidikasi terhadap TNFi (Gladman et al., 2020)

4. Psoriaris arthritis dengan spondylitis psoriasis/penyakit aksial dengan terapi NSAID

OSM tidak efektif digunakan sebagai terapi. TNFi lebih direkomendasikan daripada IL-17i atau IL-12/23i. IL-17i lebih direkomendasikan daripada IL-12/23i. IL-17i dapat digunakan sebagai terapi pengganti TNFi apabila pasien memiliki psoriasis berat atau memiliki kontraindikasi terhadap TNFi (Gladman et al., 2020).

5. Artritis Psoriatika dengan IBD (Inflammatory bowel disease).

Direkomendasikan untuk menggunakan terapi TNFi. OSM dapat digunakan pada pasien dengan Artritis Psoriatika berat yang memilih terapi oral atau memiliki kontraindikasi terhadap TNFi. IL-12/23i dapat digunakan pada pasien dengan kontraindikasi TNFi atau pasien yang memilih penggunaan obat dengan frekuensi yang lebih jarang (Gladman et al., 2020).

6. Artritis Psoriatika dengan komorbiditas

OSM direkomendasikan daripada TNFi pada pasien Artritis Psoriatika dengan diabetes pada pasien yang belum mendapat terapi sebelumnya. TNFi dapat digunakan sebagai pengganti OSM apabila pasien memiliki diabetes yang terkontrol. OSM lebih direkomendasikan daripada TNFi sebagai lini pertama pada pasien dengan infeksi serius yang berulang (Gladman et al., 2020). 
Faris Rizki Ardhan, Muhammad Akbar Hanardi, Dhila Thasliyah, Visakha Vidyadevi Wiguna, Ni Putu Yunandari

\section{Tofacitinib, Biologic Disease-Modifying Antirheumatic Drugs, dan Apremilast untuk Pengobatan PSA}

Tofacitinib merupakan salah satu obat yang dapat digunakan untuk mengobati PSA, yang berfungsi sebagai inhibitor janus kinase per oral. Uji coba tahap III yang telah dilakukan dengan durasi 6 dan 12 bulan pada pasien dengan PSA aktif dan obat yang tidak memiliki respon yang memadai untuk kategori obat csDMARD (conventional synthetic Disease-Modifying AntiRheumatic Drug) atau terapi TNFi (Tumor Necrosis Factor Inhibitor) didapatkan keamanan dan keberhasilan tofacitinib dengan dosis 5 dan 10 mg BID dalam mengobati PSA (Gladman et al., 2020).

Penelitian yang telah dilakukan oleh Gladman dkk pada 2020 dengan metode sistematik literatur review meta-analisis didapatkan tingkat keberhasilan tofacitinib 5 dan $10 \mathrm{mg}$ BID mirip dengan sebagian besar bDMARD (biologic Disease-Modifying AntiRheumatic Drug) dan apremilast dalam pengobatan penyakit persendian, serta beberapa bDMARD dalam mengatasi gejala kelainan pada kulit pada pasien dengan PSA yang TNFi-naïve (psoriatic arthritis naïve to Tumor Necrosis Factor inhibitor therapy), dan PsA yang TNFi-IR (Tumor Necrosis Factor inhibitor therapy with an Inadequate Response) (Gladman et al., 2020).

Tingkat keberhasilan serupa juga didapatkan pada perbandingan antara tofacitinib 5 dan $10 \mathrm{mg}$ BID dengan adalimumab $40 \mathrm{mg} q 2 \mathrm{w}$ (once every 2 weeks/dua minggu sekali) dan ixekizumab $80 \mathrm{mg}$ q2w atau $\mathrm{q} 4 \mathrm{w}$ dalam mengurangi DSS (Dactylitis Severity Score) dan LEI (Leeds Enthesitis Index) dari baseline pada pasien TNFi-naïve dengan PSA, dan mengurangi LEI dari baseline pada populasi pasien TNFiIR (Gladman et al., 2020).

\section{Pencegahan Artritis Psoriatika}

\section{Menjaga berat badan tetap ideal}

Obesitas lebih sering dijumpai pada individu dengan psoriasis atau Artritis Psoriatika dibandingkan pada individu yang tidak obesitas. Hubungan antara obesitas dan kondisi psoriatis dapat dikaitkan dengan sekresi aktif sitokin proinflamasi oleh jaringan adiposa yang meningkatkan $\mathrm{T}$ helper17 atau interleukin-23-mediated inflamasi yang merupakan pusatnya patogenesis psoriasis dan Artritis Psoriatika. Penurunan berat badan pada individu yang obesitas dapat menurunkan massa lemak viseral sehingga memperbaiki psoriasis melalui penurunan sitokin proinflamasi yang dilepaskan dari jaringan adiposa. Penurunan berat badan ini juga harus disertai dengan aktifitas fisik yang sesuai dengan kondisi tiap individu (Mahil et al., 2019).

\section{Mengurangi penggunaan rokok}

Merokok merupakan salah satu faktor resiko kejadian Artritis Psoriatika, Studi menunjukan bahwa pasien yang tidak merokok memiliki resiko lebih rendah terhadap kejadian Artritis Psoriatika. Untuk mencegah terjadinya resiko kejadian Artritis Psoriatika dapat dilakukan dengan berhenti atau mengurangi penggunaan rokok (Gazel et al., 2020).

\section{Deteksi dini dengan skrining}


Gejala yang paling umum dalam Artritis Psoriatika adalah nyeri sendi, kaku, dan bengkak. Serupa dengan penyakit arthritis lainnya, diagnosis dini diharapkan dapat mengontrol kerusakan sendi, biasanya terjadi dalam 2 tahun pertama penyakit. Skrining merupakan langkah awal yang penting, Adapun alat - alat skrining seperti Toronto Psoriatic Arthritis Screening (ToPAS) divalidasi dalam populasi umum dan psoriasis. the Psoriasis Epidemiology Screening Tool (PEST), the Psoriatic Arthritis Screening and Evaluation (PASE) dan Early Psoriatic Arthritis Screening Questionnaire (EARP) mempunyai struktur kuesioner yang mirip dan semuanya telah divalidasi untuk pasien dengan psoriasis. PEST, PASE, EARP dan ToPAS mencakup 5, 10, 12, 15 pertanyaan, difokuskan pada cacat fisik, gejala kulit dan sendi, semua pertanyaan berhubungan dengan nyari dan bengkak sendi. ToPAS dan PEST mencakup pertanyaan terkait dengan kuku dan jari kaki yag terkena. PEST dan EARP mengacu pada pergelangan kaki yang bengkak. Layanan Kesehatan Nasional Inggris telah merekomendasikan identifikasi awal PsA dengan kuesioner skrining dan pengujian diagnostik lebih lanjut untuk memperlambat perkembangan penyakit PsA. (Iragorri et al., 2019).

\section{Kesimpulan}

Arthrisis psoriatika (PsA) merupakan radang sendi inflamasi yang melibatkan persendian tulang belakang dan persendian lainnya. Penyakit ini dapat disebabkan oleh beberapa faktor risiko seperti faktor lingkungan, faktor genetik dan faktor imunologi. Selain itu, ada juga faktor risiko lainnya seperti obesitas, trauma fisik, merokok, lokasi psoriasis di tubuh, dan tingkat pendidikan. Terapi yang dapat dilakukan dalam mengatasi Artritis Psoriatika khususnya terapi farmakologis telah ditetapkan berdasarkan guideline rekomendasi EULAR 2019 dan ACR. Tujuan utama pengobatan pada pasien Artritis Psoriatika adalah untuk meningkatkan kualitas hidup yang berhubungan dengan kesehatan, melalui pengendalian gejala, pencegahan kerusakan struktural, serta mengembalikan fungsi sosial. Selain itu, terdapat jenis obat yang diteliti lebih lanjut, yaitu tofacitinib yang berfungsi sebagai inhibitor janus kinase per oral. Adapun pencegahan yang dapat dilakukan, yaitu menjaga berat badan tetap ideal, mengurangi penggunaan rokok, dan melakukan deteksi dini dengan skrining. 
Faris Rizki Ardhan, Muhammad Akbar Hanardi, Dhila Thasliyah, Visakha Vidyadevi Wiguna, Ni Putu Yunandari

\section{BIBLIOGRAFI}

Amy S. Kehl, Maripat Corr, and M. H. W. (2016) 'Enthesitis New Insights Into Pathogenesis, Diagnostic Modalities , and Treatment', 68(2), pp. 312-322. doi: 10.1002/art.39458. Google Scholar

Eder, L., Haddad, A., Rosen, C. F., Lee, K. A., Chandran, V., Cook, R. and Gladman, D. D. (2016) 'The Incidence and Risk Factors for Psoriatic Arthritis in Patients with Psoriasis: A Prospective Cohort Study', Arthritis and Rheumatology, 68(4), pp. 915-923. doi: 10.1002/art.39494. Google Scholar

Gazel, U., Ayan, G., Solmaz, D., Akar, S. and Aydin, S. Z. (2020) 'The impact of smoking on prevalence of psoriasis and psoriatic arthritis', Rheumatology (United Kingdom), 59(10), pp. 2695-2710. doi: 10.1093/rheumatology/keaa179. Google Scholar

Gladman, D. D., Orbai, A. M., Gomez-Reino, J., Chang-Douglass, S., Leoncini, E., Burton, H. E., Kanik, K. S., Romero, A. B., Cappelleri, J. C. and Hsu, M. A. (2020) 'Network Meta-Analysis of Tofacitinib, Biologic Disease-Modifying Antirheumatic Drugs, and Apremilast for the Treatment of Psoriatic Arthritis', Current Therapeutic Research - Clinical and Experimental. Elsevier Inc., 93. doi: 10.1016/j.curtheres.2020.100601. Google Scholar

Gossec, L., Baraliakos, X., Kerschbaumer, A., De Wit, M., McInnes, I., Dougados, M., Primdahl, J., McGonagle, D. G., Aletaha, D., Balanescu, A., Balint, P. V., Bertheussen, H., Boehncke, W. H., Burmester, G. R., Canete, J. D., Damjanov, N. S., Kragstrup, T. W., Kvien, T. K., Landewé, R. B. M., Lories, R. J. U., MarzoOrtega, H., Poddubnyy, D., Rodrigues Manica, S. A., Schett, G., Veale, D. J., Van Den Bosch, F. E., Van Der Heijde, D. and Smolen, J. S. (2020) 'EULAR recommendations for the management of psoriatic arthritis with pharmacological therapies: 2019 update', Annals of the Rheumatic Diseases, 79(6), pp. S700-S712. doi: 10.1136/annrheumdis-2020-217159. Google Scholar

Iragorri, N., Hazlewood, G., Manns, B., Danthurebandara, V. and Spackman, E. (2019) 'Psoriatic arthritis screening: A systematic review and meta-analysis', Rheumatology (United Kingdom), 58(4), pp. 692-707. doi: 10.1093/rheumatology/key314. Google Scholar

Mahil, S. K. D., Mcsweeney, S. M., Kloczko, E., Mcgowan, B., Barker, J. N., Smith, C. H. D. and Smith, C. (2019) 'Does weight loss reduce the severity and incidence of psoriasis or psoriatic arthritis? A Critically Appraised Topic', pp. 1-8. doi: 10.1111/bjd.17741. Google Scholar

Ocampo, V. and Gladman, D. (2019) 'Psoriatic arthritis', F1000Research. Faculty of 1000 Ltd, 8. Google Scholar

Rendon, A. and Schäkel, K. (2019) 'Psoriasis pathogenesis and treatment', International Journal of Molecular Sciences, 20(6), pp. 1-28. doi: 10.3390/ijms20061475. Google Scholar 
Segar, D., Praharsini, I. and Indira, I. E. (2019) 'Prevalence and clinical manifestations of patients with psoriasis in RSUP Sanglah from 2017 to 2018', Intisari Sains Medis, 10(3), pp. 840-844. doi: 10.15562/ism.v10i3.497. Google Scholar

Singh, G., Gehr, T., Püschel, M. and Vechev, M. (2018) 'Boosting robustness certification of neural networks', in International Conference on Learning Representations. Google Scholar

First publication right:

Jurnal Syntax Fusion: Jurnal Nasional Indonesia

This article is licensed under:

(ㅇ) (1) ( ) 